\title{
EMPIRICAL DIVERSITY INDICES APPLIED TO FOREST COMMUNITIES IN DIFFERENT SUCCESSIONAL STAGES
}

\author{
PETRERE Jr., M., ${ }^{1}$ GIORDANO, L. C. ${ }^{1}$ and De MARCO Jr., P. ${ }^{2}$ \\ ${ }^{1}$ Departamento de Ecologia, UNESP, C.P. 199, CEP 13506-900, Rio Claro, SP, Brazil \\ ${ }^{2}$ Laboratório de Ecologia Quantitativa, Departamento de Biologia Geral, Universidade Federal de Viçosa, \\ CEP 36570-000, Viçosa, MG, Brazil \\ Correspondence to: Miguel Petrere Jr., Departamento de Ecologia, UNESP, C.P. 199, \\ CEP 13506-900, Rio Claro, SP, Brazil, e-mail: mpetrere@ rc.unesp.br \\ Received April 7, 2003 - Accepted October 16, 2003 - Distributed November 30, 2004 \\ (With 3 figures)
}

\begin{abstract}
In this paper we examine the precision of six diversity indices, four of them empirical when including in their formulae climax adaptation numbers. These numbers define the succession position of the plant species in five forest areas in São Paulo State. We simulated hypothetical forests and compared the results with a list of species in the five areas. Low agreement was found among the indices in succession stages. Including the climax adaptation numbers increased precision for only some indices.
\end{abstract}

Key words: diversity indices, climax adaptation numbers, seral stages, tropical forests, Brazil.

\section{RESUMO}

\section{Índices empíricos de diversidade aplicados a comunidades florestais em diferentes estágios de sucesão}

Neste trabalho, examinamos a precisão de seis índices de diversidade, quatro deles empíricos, ao incorporarmos em suas fórmulas os números de adaptação climáxica, que definem a posição da espécie na sucessão vegetal em cinco áreas florestais no Estado de São Paulo. Foram realizadas simulações em florestas hipotéticas, comparando seus resultados com listagem de espécies das cinco áreas florestais analisadas. Há baixa concordância entre os índices no meio da sucessão ecológica. Conclui-se, portanto, que para alguns índices os números de adaptação climáxica aumentam sua precisão, já para outros não.

Palavras-chave: índices de diversidade, números de adaptação climáxica, estágios serais, florestas tropicais, Brasil.

\section{INTRODUCTION}

In several ecological studies a major role is played by succession, which is defined as the ordered sequence of community development due to the action of vegetation upon the environment, leading to further colonization by new species (Krebs, 1986; Pickett, 1976). According to Odum (1969), this process involves changes in the biotic (which refers to community structure) and abiotic components of the ecosystem. The biotic component controls the succession, but the abiotic dictates its pattern and velocity.

Different models for plant community succession have been produced since the general facilitation- competition model of Clements (1916). The original model was rejected on some grounds, mainly because of the existence of discrete succession stages (Pickett, 1976), but many of the original ideas were maintained in our current understanding of this phenomenon. Connell \& Slatyer (1977) provided a general analysis of the mechanisms of succession and added to the original competition-facilitation model the tolerance and the inhibition models. The main difference between these models lies in the mechanisms which determine how new species appear later in the sequence.

The order of appearance of a new species in the community is referred to as the seral stage; the 
definition of which, however, is not clearcut. Curtis $\&$ McIntosh (1951) classified succession in ten different stages, conferring upon them climax adaptation numbers, a system giving increasing weight to each species according to its order of appearance during the process, beginning from the pioneer (1) to the climax (10) species. Nowadays, successional studies attribute great importance to diversity and its measurement, which is one of the main themes in Ecology.

One important aspect of these studies is their utility in assessing the restoration process in terrestrial (Connell \& Slatyer, 1977) and aquatic ecosystems (Pearson \& Rosenberg, 1978; Zajac \& Whitlatch, 1982; Gallagher et al., 1983). It is important to note that forest restoration can be viewed as the acceleration of the natural successional process toward climax. Within this approach, a quantitative analysis capable of comparing the successional status of different areas would be a desirable methodology in evaluating restoration programs.

The general Clementsian succession model states that communities closer to climax are more diverse (Clements, 1916). However, other researchers maintain that higher diversity is only attained in areas with an intermediate disturbance regime (Pickett, 1976; Connell, 1978) and that diversity is not a monotonic function of succession. In these respects, climax adaptation numbers represent a much more functional community describer that is not affected by how diversity increases but only with the biological characteristics of the component species of the community. In this paper, we therefore suggest some new diversity indices that are also functions of the biological characteristics of the species and which also represent attempts to mitigate this shortcoming.

To determine the usefulness of these indices we examine their statistical properties by means of a simulation analysis based on computer-generated communities. We also provide real data examples to show the reliability of their interpretation with respect to community analysis and environmental impact assessment.

\section{METHODS}

In this work we perform a simulation analysis of artificial communities with known variances and the lognormal species abundance model. We also carry out an analysis using five lists of arboreal species, from surveys made by different authors in São Paulo State, Brazil.

\section{Climax adaptation numbers}

The surveys by Giannotti et al. (unpublished report), Gandolfi (1991), and Sanchez (personal communication to M. Petrere Jr.) already presented a species classification according to successional rank. For the other surveys we set up a classification according to Gandolfi (1991), Costa (1992), Lorenzi (1992), Cersósimo (1993), Leitão (1993, 1995), Roizman (1993), Rodrigues (1995), Ferretti et al. (1995), Knobel (1995), Mantovani (1993, and a personal communication to L. C. Giordano), Tabarelli (1994), Pagano et al. (1995 and personal communication to M. Petrere Jr.). Only those individuals identified at the species level were considered, as the climax numbers could be dubious with respect to genera. For several species we found different and, in some cases, opposite opinions about their rank. In such cases only one final classification was adopted.

Criteria chosen were: for those surveys with a previous classification, the original author classification was adopted. The two surveys related to mesophilous forest not previously classification, were ordered in accordance with similar vegetation types in similar succession stages. For diverging classifications we prioritized the authors in the following order: Pagano et al. (1995, and personal communication to M. Petrere Jr.), Gandolfi (1991), Mantovani (personal communication to L. C. Giordano), Rodrigues (1995), Lorenzi (1992), Ferretti et al. (1995), Cersósimo (1993), Knobel (1995), Roizman (1993), Tabarelli (1994), and Costa (1992). At the end, we adopted only three climax adaptation numbers: $\mathrm{w}_{\mathrm{i}}=1,2,3$ for pioneering, intermediary, and climax species, respectively, according to Gandolfi (1991) who adopted the following classification:

1. pioneering species: those capable of developing in clearings at the forest edges or in open sites, and clearly dependent on increasing luminosity. These species do not occur in the understory;

2. initial secondary species: those not found in dense shading but capable of growing under conditions of increased luminosity in small clearings, edges of larger clearings, or at forest edges, and which also occur in the understory, mainly in areas having milder shading; 
3. late secondary species: those capable of developing in the understory, remaining there for the entire life cycle or reaching the canopy. Costa (1992) and Leitão (1993, 1995) adopted this classification.

\section{Diversity indices}

We examine four new empirically based diversity indices, which take into account climax adaptation numbers:

1. Successional index (SI)

$$
S I=\sum_{i=1}^{s} w_{i} p_{i}
$$

where:

$\mathrm{w}_{\mathrm{i}}$ is the climax adaptation number already defined $\left(\mathrm{w}_{\mathrm{i}}=1,2,3\right) ; \mathrm{p}_{\mathrm{i}}$ is the percent of species $j$ in the survey $\left(p_{i}=n_{i} / N\right.$, where $n_{i}$ is the abundance of species $\mathrm{i}$; and $\mathrm{N}=\sum_{i=1}^{s}$ $\mathrm{n}_{\mathrm{i}}$ is the total number of individuals and $\mathrm{s}$ is the total number of species in the survey). $(1 \leq \mathrm{S} \mathrm{I} \leq 3)$

2. Weighed successional index (WSI)

$$
W S I=\frac{\sum_{i=1}^{s} w i \cdot p_{i}}{\sum_{i=1}^{s} w_{i}}
$$

3. Modified Shannon-Weaver index $\left(\mathrm{H}_{\mathrm{w}}{ }^{\prime}\right)$

$$
H^{\prime}{ }_{w}=-\sum_{i=1}^{s} w_{i} \cdot p_{i} \cdot \ln p_{i}
$$

$\mathrm{H}^{\prime} \leq \mathrm{H}^{\prime}{ }_{\mathrm{w}} \leq 3 \mathrm{H}^{\prime}$ (if all $\mathrm{w}_{\mathrm{i}}=1, \mathrm{H}_{\mathrm{w}}{ }_{\mathrm{w}}=\mathrm{H}^{\prime}$, and if all $\mathrm{w}_{\mathrm{i}}=3, \mathrm{H}_{\mathrm{w}}{ }_{\mathrm{w}}=3 \mathrm{H}^{\prime}$ ).

4. Modified Simpson index $\left(\mathrm{D}_{\mathrm{w}}\right)$

$$
D_{w}=\frac{\left(3-\sum_{i=1}^{s} w_{i \cdot} \frac{n_{j} \cdot\left(n_{j}-1\right)}{N(N-1)}\right)}{3}
$$

The reason for the number 3 in the formula is simply to scale $\mathrm{D}_{\mathrm{w}}$ from 0 to 1 .

The calculations of these indices were performed using the jackknife technique with the computation of their variances (Sokal \& Rohlf, 1995).

\section{Simulations}

To establish the intrinsic properties of these indices, we simulated building communities with aggregated spatial patterns and composition that try to mimic common tropical successional patterns.

We employed a modified Thomas process (Diggle et al., 1976; Heltshe \& Bitz, 1979; Heltshe \& Forrester, 1985) to distribute the individuals of each species in a $100 \times 100$ grid. In this procedure we distributed "parents" in the grid at random. The "offspring" were then distributed around the parents by drawing an angle, uniformly distributed between $0^{\circ}$ and $180^{\circ}$, and a distance, normally distributed with mean 0 and variance $\boldsymbol{\sigma}^{2}$. The number of offspring associated with each parent had a Poisson distribution, the mean being equal to $10 \%$ of the species population. The degree of clumping is inversely related to $\boldsymbol{\sigma}^{2}$ so that low $\boldsymbol{\sigma}^{2}$ values produce tight offspring distribution.

In all simulations the abundance patterns between species were assumed to be lognormally distributed, which was done by taking the exponential function to a normally distributed random variate with appropriate means and variance so as to assure that the total abundance of the community be constrained to a predefined value. These numbers were rounded to integers. The normally distributed variate was produced by a standard normal random number generator.

Lognormal distribution was adopted because it is expected in species-rich assemblages (Magurran, 1988; May, 1975).

The number of species in each group (pioneers, mid-succession, and mature) were under control. Four community types were simulated to mimic early successional stage, mid-sucession, and mature forest. The main properties of these communities that we try to explore are increase in species richness and distribution patterns of species number between successional groups. Table 1 presents the main properties of these artificial communities.

\section{Description of the areas}

We utilized the surveys from two areas located in the Parque Estadual da Serra do Mar, Núcleo Picinguaba, Ubatuba (SP), one of which is classified as hillside rainforest and the other as a riparian hillside rainforest. We also considered three areas classified as mesophilous semidecidual forest.

We decided to choose just those surveys based on the plot method to facilitate computer program- 
ming, in addition to which colleagues with field data to share were not always available.

Area 1 - located in the municipality of Campinas, in Santa Genebra reserve (Rodrigues \& Shepherd, unpublished report).

This is a 252 ha urban reserve having a complex pattern with areas that were selectively exploited for their valuable plant species while others were completely cut. At present it has clearings in different successional stages. The survey was carried out in a $50 \times 200 \mathrm{~m}$ area, divided into $10,010 \times 10 \mathrm{~m}$ plots in which only individuals with perimeters above 5 $\mathrm{cm}$ were considered. A total of 1,449 individuals are distributed among 96 species. No further information was originally reported by the above authors.

Area 2 - Guarulhos woods, located in the municipality of Guarulhos (Gandolfi, 1991).

According to Gandolfi (1991), the historical survey of this area started in 1937 when it was a private area donated to the Army for building a military airport. Until 1945 the area continued as isolated spots of forest, which were exploited for charcoal. To restore the forest, an artificial aerial seeding was done using species unidentified by their scientific names. No records exist of follow-up. The area was relatively protected for 35 years and, although military training continued, tree felling for charcoal diminished. In 1984, 70\% of the area was cut in preparation for building São Paulo's second international airport. From 1983 to the beginning of airport construction, a sampling covering a 52,800 $\mathrm{m}^{2}$ area was performed in contiguous $20 \times 20 \mathrm{~m}$ plots, totalling 132 plots of which $67\left(26,800 \mathrm{~m}^{2}\right)$ were surveyed. Only those individuals with more than $1.5 \mathrm{~m}$ in height were considered. A total of 1726 individuals were found, distributed among 91 species.

Area 3 - located at the São José farm in the municipality of Rio Claro (Pagano et al., 1995).

According to Pagano et al. (1995) the studied area has about 230 ha of dense forest, the canopy ranging from 15 to $30 \mathrm{~m}$ in height, with emerging individuals and no marked stratification. There are clearings due to fallen trees, in some of which lianas are very abundant; epiphytes are also present. In this area $4410 \mathrm{~m} \times 10 \mathrm{~m}$ plots were sampled; these were distributed at random on trail edges, where arboreal individuals with stems above $1.3 \mathrm{~m}$ were tallied. A total of 1,908 individuals was distributed among 136 species.

Area 4 - located in the Parque Estadual da Serra do Mar (Núcleo Picinguaba), a hillside rainforest in the municipality of Ubatuba.

The species survey by Giannotti et al. (unpublished data) covered a $1,000 \mathrm{~m}^{2}$ area in the Atlantic Forest, considered by these authors as being in initial succession stages as the area was completely cleared during the construction of the Rio-Santos Highway in the 70s. The sampling was performed in 10 contiguous $10 \times 10 \mathrm{~m}$ plots; only individuals measuring above $20 \mathrm{~cm} \mathrm{DBH}$ (diameter at breast height equal to $1.30 \mathrm{~m}$ ). A total of 120 individuals were distributed among 25 species.

Area 5 - also located in the Parque Estadual da Serra do Mar (Núcleo Picinguaba), a hillside riparian rainforest in the municipality of Ubatuba.

The survey by Sanchez (1994) was carried out on the banks of the Fazenda river, in a relatively better preserved area under the influence of the river's hydrological regime. A 4,000 $\mathrm{m}^{2}$ area was sampled, divided into 10 random $10 \times 10 \mathrm{~m}$ plots, and taking into account just individuals with perimeters exceding $20 \mathrm{~cm}$ (corresponding to about $1.30 \mathrm{~m}$ in height). A total of 647 individuals were found, distributed among 105 species.

\section{RESULTS}

The extensive species list with their respective climax adaptation numbers are found in Giordano (1996). Table 2 shows the mean standard deviation and coefficient of variation for each of the four proposed indices and for the usual Shannon-Weaver $\left(\mathrm{H}^{\prime}\right)$ and Simpson (1-D) diversity indices. Note that with the exception of area $1, D_{w}$ presents the lowest coefficient of variation, indicating that the inclusion of the climax adaptation numbers into the Simpson diversity index increased its precision, which is not true for $\mathrm{H}^{\prime}{ }_{\mathrm{w}}$ when compared to H'. The SI and WSI have virtually the same precision.

Fig. 1 presents these indices classifed according the $\mathrm{H}^{\prime}$ values. Both diversity indices $\left(\mathrm{H}^{\prime}\right.$ and 
1-D) appear to reveal that communities 4 and 3 have high spatial heterogeneity with large standard deviation. As these indices were estimated by the jackknife procedure, the standard deviation ultimately represents spatial variation due to inclusion of each sampling unit in the sample.

Little concordance exists between diversity and the successional index except perhaps in the case of
$\mathrm{H}_{\mathrm{w}}$. Indices $\mathrm{SI}$ and $\mathrm{H}_{\mathrm{w}}$ agree on community 4 being closest to initial stages. Based on $\mathrm{H}^{\prime}{ }_{\mathrm{w}}$, communities 5 and 3 were considered closer to the climax, and community 1 was added to this group based on the SI index. The WSI produced the largest discrepancy between initial and middle-late successional stages when compared to the other indices. Index $\mathrm{D}_{\mathrm{w}}$ appears not to agree with the others in any aspect.
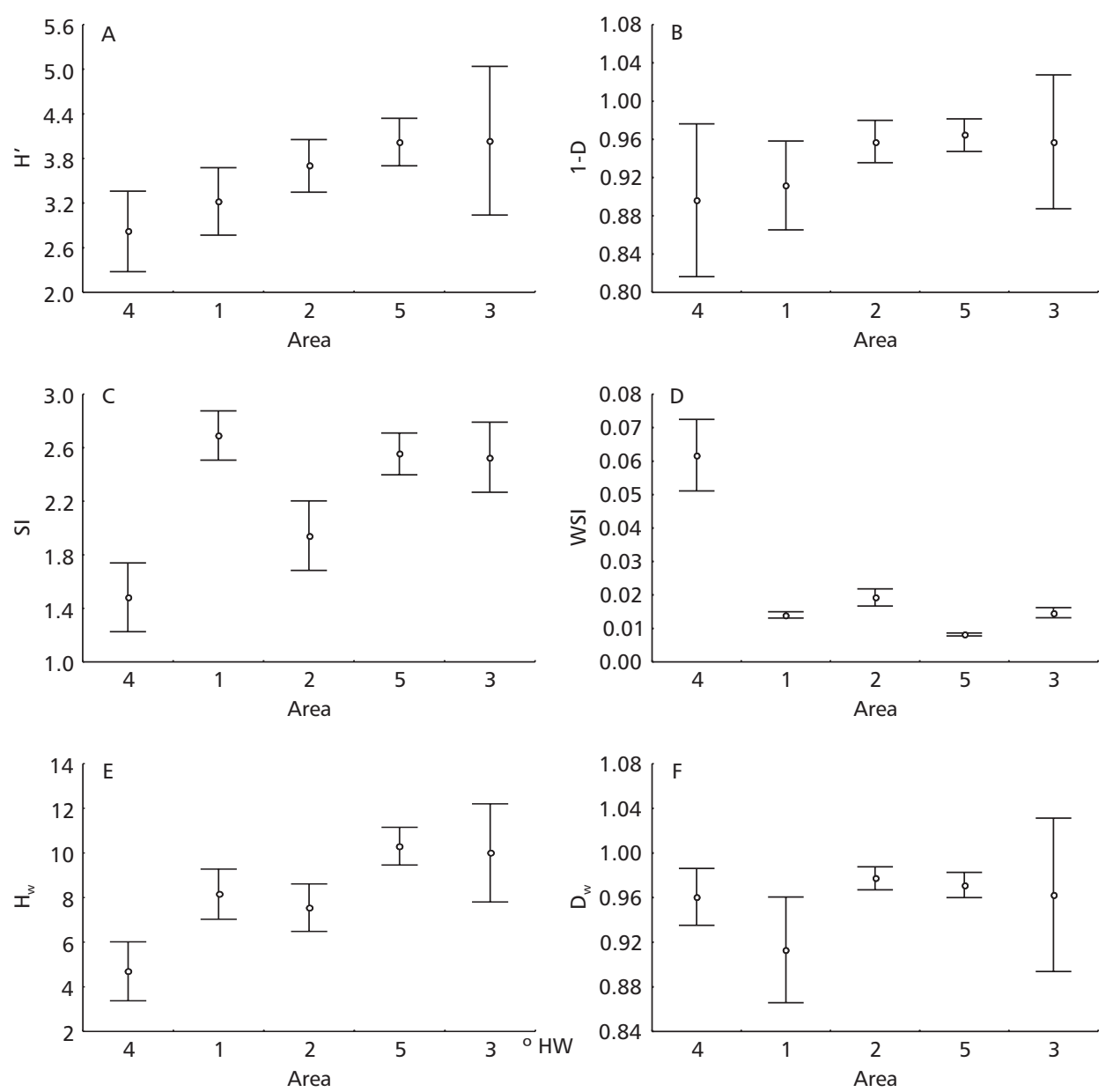

Fig. 1 - Mean values (bars represent standard deviations) of the successional index in the five studied areas (A - Shannon H'; B - Simpson (1-D); C - Successional Index SI; D - Weighted Successional index WSI; E - H' ${ }_{w}$; $-D_{w}$ ). 
TABLE 1

Structure of theoretical communities used in the simulation experiments $\left(S^{*}-\right.$ number of species).

\begin{tabular}{|l|c|c|c|c|}
\hline \multicolumn{1}{|c|}{ Community type } & S* $^{*}$ & Pioneer & Mid-succession & Mature \\
\hline Early succession & 40 & 40 & 0 & 0 \\
\hline Mid-succession & 60 & 10 & 40 & 10 \\
\hline Mature1 & 80 & 10 & 45 & 25 \\
\hline Mature 2 & 100 & 10 & 30 & 60 \\
\hline
\end{tabular}

TABLE 2

Mean $(\bar{X})$, standard deviation (s) and coefficient of variation (\%) for SI, WSI, H', ${ }^{\prime}, \mathbf{D}_{w}$, and 1-D. Area 1 Santa Genebra reserve; Area 2 - Guarulhos woods; Area 3 - São José farm; Area 4 - Núcleo Picinguaba, data from Gianotti et al. (unpublished): Area 5 - Núcleo Picinguaba, data from Sanchez (1994). Boldface indicates the lowest $\mathrm{CV}$ in each respective row.

\begin{tabular}{|c|c|c|c|c|c|c|c|}
\hline Area & & SI & WSI & $\mathbf{H}^{\prime}{ }_{\mathbf{w}}$ & $\mathbf{D}_{\mathbf{w}}$ & $\mathbf{H}^{\prime}$ & $\mathbf{1 - D}$ \\
\hline \multirow{4}{*}{1} & $\bar{X}$ & 2.693 & 0.014 & 8.150 & 0.913 & 3.223 & 0.912 \\
\cline { 2 - 8 } & $S$ & 0.184 & 0.0009 & 1.122 & 0.047 & 0.453 & 0.0465 \\
\cline { 2 - 8 } & $C V$ & $6.84 \%$ & $6.84 \%$ & $13.76 \%$ & $5.19 \%$ & $14.06 \%$ & $4.32 \%$ \\
\hline \multirow{4}{*}{2} & $\bar{X}$ & 1.943 & 0.019 & 7.545 & 0.977 & 3.703 & 0.958 \\
\cline { 2 - 8 } & $S$ & 0.259 & 0.002 & 1.065 & 0.010 & 0.355 & 0.022 \\
\cline { 2 - 8 } & $C V$ & $13.34 \%$ & $13.37 \%$ & $14.12 \%$ & $1.05 \%$ & $9.58 \%$ & $2.31 \%$ \\
\hline \multirow{4}{*}{3} & $\bar{X}$ & 2.524 & 0.015 & 10.001 & 0.962 & 4.038 & 0.957 \\
\cline { 2 - 8 } & $S$ & 0.262 & 0.001 & 2.200 & 0.069 & 1.001 & 0.070 \\
\cline { 2 - 8 } & $C V$ & $10.38 \%$ & $9.81 \%$ & $17.25 \%$ & $7.14 \%$ & $24.78 \%$ & $7.31 \%$ \\
\hline \multirow{4}{*}{4} & $\bar{X}$ & 1.483 & 0.0618 & 4.693 & 0.961 & 2.819 & 0.896 \\
\cline { 2 - 8 } & $S$ & 0.257 & 0,011 & 1,320 & 0,025 & 0,541 & 0,080 \\
\cline { 2 - 8 } & $C V$ & $17.31 \%$ & $17.41 \%$ & $28.12 \%$ & $2.66 \%$ & $19.19 \%$ & $8.92 \%$ \\
\hline \multirow{3}{*}{5} & $\bar{X}$ & 2.554 & 0.008 & 10.302 & 0.971 & 4.020 & 0.964 \\
\cline { 2 - 8 } & $S$ & 0.156 & 0.0004 & 0.847 & 0.011 & 0.320 & 0.017 \\
\cline { 2 - 8 } & $C V$ & $6.11 \%$ & $5.25 \%$ & $8.22 \%$ & $1.16 \%$ & $7.95 \%$ & $1.76 \%$ \\
\hline
\end{tabular}

In the simulation experiment (Fig. 2) the first important result is the large standard deviations associated with the Simpson index. There is much more agreement between the species diversity index and the successional index ( $\mathrm{SI}$ and $\mathrm{H}_{\mathrm{w}}^{\prime}$ ), and to a less extent to WSI.

Due to the successional information, SI and $\mathrm{H}^{\prime}{ }_{\mathrm{w}}$ showed better than the diversity indices that the 10:40:10 and 10:45:15 (number of species in the pioneer:middle:mature stages) of the two communities are closer together. A comparison of the results of the real and simulated communities showed that the discrepancies observed between the diversity index and successional indices represent the different aspects weighted in them, specially in the middle successional stages. There is a general agreement between the initial and climax stages but diversity indices are poor descriptors for middle successional stages.

In general, the initial stages showed the largest coefficient of variation for all indices (Fig. 3). In fact, the most precise index was the SI and $\mathrm{H}^{\prime}{ }_{\mathrm{w}}$. The Simpson index and the other based on it $\left(\mathrm{D}_{\mathrm{w}}\right)$ proved to be less precise. 


\section{DISCUSSION}

It is well established that tropical forests are highly diverse, which has to be taken into consideration when examining their dynamics as is the case in succession studies. In understanding this process, much effort has been directed to species classification according to an adopted successional categorization. Pioneering work on humid tropical forests was done by Budowski (1965) who regarded as relevant the following community characteristics: age; tree height; number of arboreal species; distribution and floristic composition of dominant species; number of strata; canopy and lower strata characteristics; shade tolerance; regeneration intensity of dominant species; seed size, dissemination, and viability; fruit dispersal; wood types and $\log$ diameters; leaf permanence; presence of epiphytes, lianas, shrubs, and herbaceous vegetation.
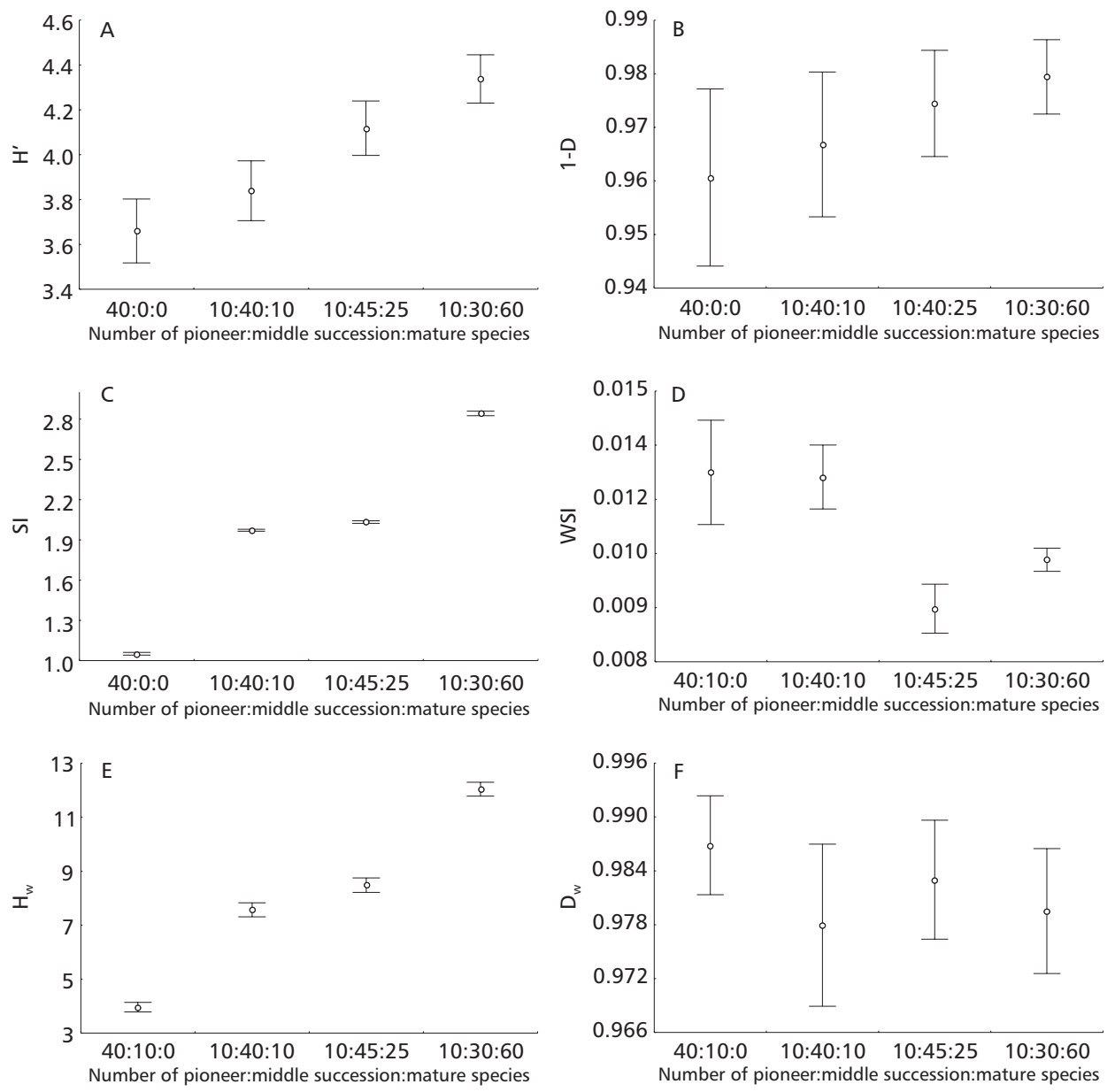

Fig. 2 - Mean values (bars represent standard deviations) of the successional index in the 5000 simulations of different numbers of species in the successional categories pioneer (40:0:0); middle-succession (10:40:10), mature ${ }_{1}(10: 45: 25)$ and mature ${ }_{2}(10: 30: 60)$ (A - Shannon H'; B - Simpson (1-D); C - Successional index SI; D - Weighted Successional index WSI; E - H' ${ }_{\mathrm{w}}$; F - D ${ }_{\mathrm{w}}$ ). All simulations based on tight aggregation: variance of the Thomas process equals 100 . 

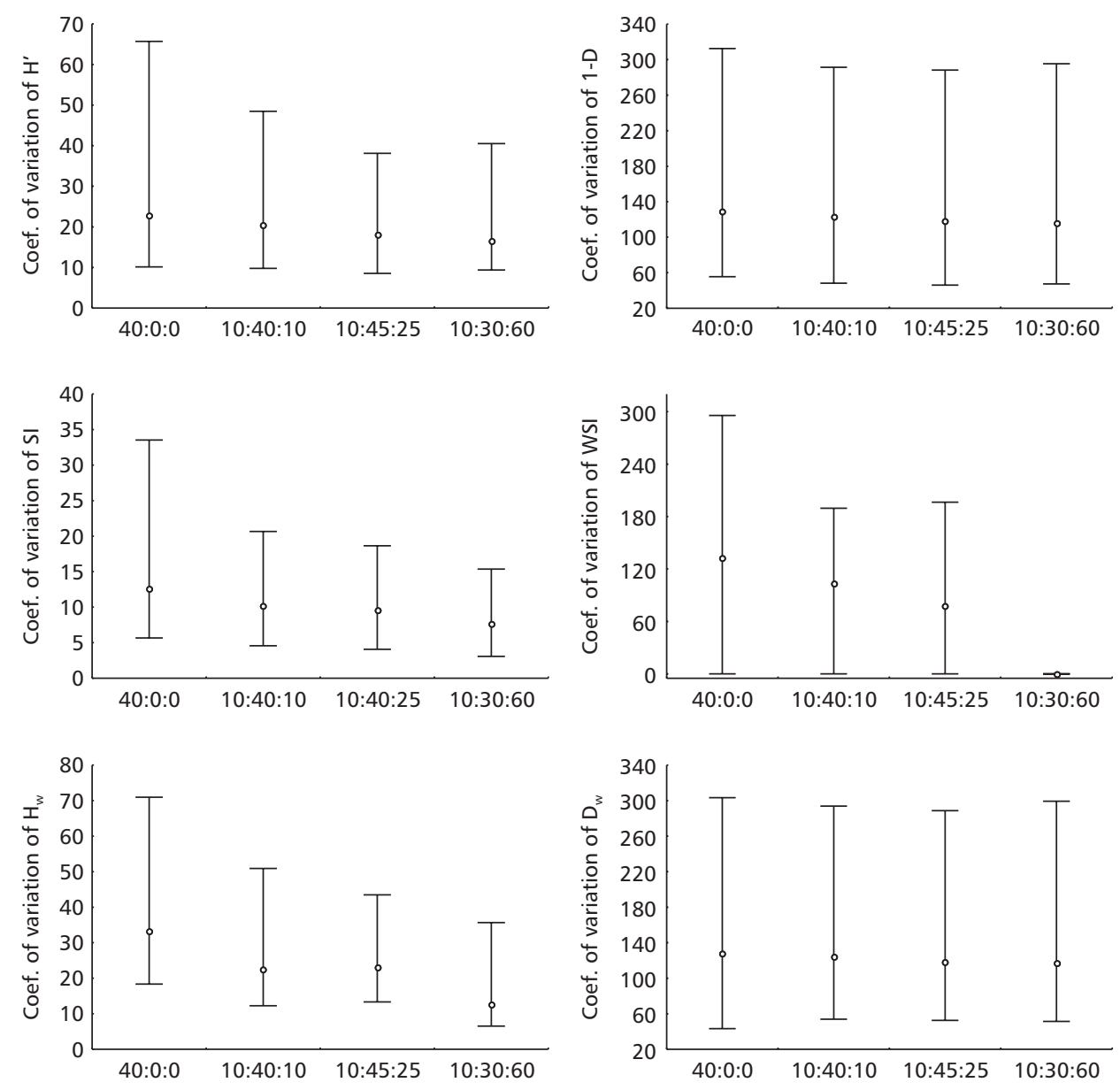

Fig. 3 - Mean values (bars represent standard deviations) of the coefficient of variation of successional index in 5,000 simulations of different numbers of species in the successional categories pioneer (40:0:0); middle-succession (10:40:10), mature ${ }_{1}(10: 45: 25)$ and mature (10:30:60) (A - Shannon H'; B - Simpson (1-D); C - Successional index SI; D - Weighted Successional index WSI; $\mathrm{E}-\mathrm{H}_{\mathrm{w}} ;{ }_{\mathrm{F}} ; \mathrm{D}_{\mathrm{w}}$ ). All simulations based on tight aggregation: variance of the Thomas process equals 100.

Tropical forest species categorization is controversial because the majority of species to be considered have been poorly studied individually (Rodrigues, 1995). The main aspects of plant biology used in classification schemes have been plant responses to forest clearing, seed germination, dispersal ability, and growth pattern (Denslow, 1980; Whitmore, 1989; Cersósimo, 1993; Mantovani, 1993; Tabarelli, 1994; Pagano et al., 1995; Knobel, 1995; Ferretti et al., 1995). The number of categories established has varied between 2 (e.g., Whitmore, 1989) to 5 (e.g., Cersósimo, 1993).
We believe that the use of three categories would minimize the divergency among those established in work of several authors. Further refinement would be more subjective and debatable.

According to Mantovani (1993), successional classification varies according to forest structures and so a given species may appear later in one community and earlier in another. These differences would be due to interaction among diverse characteristics in geology, pedology, relief, hidrography, and climate (Klein, 1990). Thus, of our original data set consisting of 368 species, 130 presented non- 
coincidental climax numbers. Of these, 114 where classified in contiguous groups; the remaining 16 were classified as pioneer and climax in distant groups. Finally, some species (12 out of 16) were classified in all levels.

The indices proposed here are empirical, not mathematically derived as are the original ShannonWeaver and Simpson indices (Pielou, 1976). In this way their modifications $\left(\mathrm{H}_{\mathrm{w}}\right.$ and $\left.\mathrm{D}_{\mathrm{w}}\right)$ must be viewed only with the objective of assessing their functionality, as was done by Qinghong (1995). The SI and WSI do not compromise diversity since they only measure the average successional grade of a forest community. The SI varies from 1 (all the species are pioneers) to 3 (all the species are climaxic). The WSI has no minimum nor maximum values as $\sum_{i=1}^{3} \sum_{j=1}^{s} \mathrm{w}_{\mathrm{i}, \mathrm{j}}$ depends on the number of species in the community, which may possibly be regarded as a shortcoming when WSI is analyzed separately, since it would be difficult to classify a community as near to or far from the climax. So WSI must be used only comparatively, in which case weighing is an advantage.

The simulation analysis revealed that the common species diversity measures failed in many respects as community succession measures. First of all, Simpson 1-D had very low precision compared to all other measures. The H' and 1-D failed to detect that a community with 10:45:25 (pioneer: middle succession: climax number of species) was only a bit closer to climax than a 10:40:10 community. These failures appear to be most important in the middle successional stages.

The second important point is that species diversity is a phenomenological measure of succession. The actual succession mechanism should include an increase of species diversity but as a functional modification of the community as included species would be allocated to different successional categories (or climax adaptation numbers). Only counting species number or species abundance tells us nothing about their functional importance in the community and conceals community processes, especially succession. As a direct measure of the proportion of species in functional groups, successional indices could provide a more realistic and operational measure to evaluate community change during succession.

Failure of the diversity index in middle successional stages would also be predicted because diversity does not increase monotonically with succession (Pickett, 1976). Maximum diversity is predicted for the middle successional stages when pioneer and late species overlap. Species diversity and, in some cases, species richness are not proper descriptors for successional stages because the funcional features of the community are lost in these indices. The successional indices presented here, because relying on climax adaptation numbers, reveal more accurately the current status of a given system.

Since the SI and $\mathrm{H}^{\prime}$ were able to detect the similarity between 10:45:25 and 10:40:10 communities, they were considered reliable measures. They also had the lowest coefficients of variation during the simulation experiment. Nevertheless, for the field data they usually presented higher coefficients of variation than did $D_{w}$. The main reason for these discrepancies is the difference in spatial distributions and abundance distributions in the field data.

We considered both SI and $\mathrm{H}^{\prime}$, good successional indices based on consistence and precision criteria. But in comparative studies, SI had an advantage due to its limits in variation (0 to 3 ). Successional status interpretation was favored, but could be misleading in many cases. By definition, the climax maintains species of initial categories, but the climax for a particular area could be far below $\mathrm{SI}=3$.

For all purposes, these indices could be used to compare different patches in the same vegetation, different periods in the same patch, or even different localities in the same region. A biological assumption as to these comparisons is that a common climax is to be expected in samples being compared. We strongly suggest that in restoration studies a biological term of comparison be allowed and a primary habitat sampled as a control with respect to expected values for climax.

It is also obvious that the use of these indices is only acceptable within the same methodological framework. In phytosociological studies this means the same method (plot or distance sampling), same community definition (same diameter at chest height and same taxonomic level determination). The jackknife procedure is sensitive to species spatial distribution differentially determined by the plot or distance methods, and precludes a comparison between them.

The most important advantage of the use of the jackknife procedure is that it makes it possible to estimate the standard error, so these indices could be compared using confidence interval estimates 
performed in the usual way (Manly, 1991). This approach allows us to make a proper statistical test, for example, of a hypothesis that a particular restoration process would produce better results than would another during a fixed time interval.

Acknowledgements - To UNESP, UFV and CNPq for the financial support. Professor Waldir Mantovani - USP - Department of Botany is thanked for his suggestions and constructive criticisms.

\section{REFERENCES}

BUDOWSKI, G., 1965, Distribuition of tropical American rain forest species in the light of sucessional processes. Turrialba 15: 23-31.

CERSÓSIMO, L. F., 1993, Variações espaciais e temporais no estabelecimento de plântulas em trecho de floresta secundária em São Paulo, SP. Dissertação de Mestrado, I.B/SP, São Paulo, 195p.

CLEMENTS, F. E., 1916, Plant succession: an analysis of the development of vegetation. Carnegie Institution of Washington, Publ. 242, Washington, DC, 63p.

CONNELL, J. H., 1978, Diversity in tropical rain forest and coral reefs. Science, 199: 1302-1310.

CONNELL, J. H. \& SLATYER, R. O., 1977, Mechanisms of succession in natural communities and their role in community stability and organization. The American Naturalist, 111: 1119-1144.

COSTA, L. G. S., 1992, Estrutura e dinâmica de trecho de mata mesófila semidecídua, na Estação Ecológica de Ibicatú, Piracicaba, SP. Dissertação de Mestrado, IB/SP, São Paulo, 186p.

CURTIS, J. T. \& McINTOSH, R. P., 1951, An upland forest continuum in the prairie-forest boreder region of Wisconsin. Ecology, 32: 476-496

DENSLOW, J. S., 1980, Gap partitioning among tropical rainforest trees. Tropical succesion, 12 (supplement): 47-55.

DIGGLE, P. J., BESAG, J. E. \& GLEAVES, J. T., 1976, Statistical analysis of spatial point patterns by means of distance methods. Biometrics, 32: 659-667.

FERRETI, A. R. et al., 1995, Classificação das espécies arbóreas em grupos ecológicos para revegetação com nativas no Estado de São Paulo. Florestal Estatístico, 3(7): 73-77.

GALLAGHER, E. D., JUMARS, P. A. \& TRUEBLOOD, D D., 1983, Facilitation of soft-bottom benthic succession by tube builders. Ecology, 64: 1200-1216.

GANDOLFI, S., 1991, Estudo florístico e fitossociológico de uma floresta residual na área do aeroporto internacional de São Paulo, município de Guarulhos, SP. Dissertação de Mestrado, UNICAMP, Campinas, SP, 167p.

GIANNOTTI, E., LEITÃO, H. F., CÉSAR, O. \& PAGANO, S. N. Fitossociologia da vegetação arbórea da Mata Atlântica numa área perturbada, em Picinguaba (Estado de São Paulo). Unpublished report.
GIORDANO, L. C., 1996, Novos índices de diversidade aplicados a comunidades arbóreas em diferentes estágios de sucessão ecológica. Trabalho de Graduação em Ecologia, IB/UNESP, Rio Claro.

HELTSHE, J. F. \& BITZ, D. W., 1979, Comparing diversity measures in sampled communities, pp. 133-144. In: J. F. Grassle, G. P. Patil, W. Smith \& C. Taillie (eds.), Ecological diversity in theory and practice. International Cooperative Publishing House, Fairland, Maryland.

HELTSHE, J. F. \& FORRESTER, N. E., 1985, Statistical evaluation of the jackknife estimate of diversity when using plot samples. Ecology, 66: 107-111.

KLEIN, R. M., 1990, Estrutura, composição florística, dinamismo e manejo da "Mata Atlântica" (Floresta ombrófila densa) no sul do Brasil. In: II Simpósio de Ecossistemas da Costa Sul e Sudeste Brasileira, Estrutura, Função e Manejo. pp. 259-286.

KNOBEL, M. G., 1995, Aspectos da regeneração natural do componente arbóreo-arbustivo, de trecho da floresta da reserva biológica do Instituto de Botânica em São Paulo, SP. Dissertação de Mestrado, IB/SP, São Paulo, 88p.

KREBS, C. J., 1986, Ecologia. Análisis Experimental de la Distribuición y Abundancia. Ediciones Pirámide, Madrid, Espanha, 806p.

LEITÃO, H. F. (ed.), 1993, Ecologia da Mata Atlântica de Cubatão. UNESP; UNICAMP, 184p.

LEITÃO, H. F., 1995, A vegetação da Reserva de Santa Genebra, pp. 19-29. In: P. C. Morellato \& H. F. Leitão Filho (eds.), Ecologia e preservação de uma floresta tropical urbana, reserva de Santa Genebra. UNICAMP, Campinas (SP).

LORENZI, H., 1992, Árvores Brasileiras. Plantarum, Piracicaba (SP), 351p.

MAGURRAN, A. E., 1988, Ecological diversity and its measurement. Chapman and Hall, London, 179p.

MANLY, B. F. J., 1991, Randomization and Monte Carlo methods in biology. Chapman and Hall, London, 281p.

MANTOVANI, W., 1993, Estrutura e dinâmica da floresta atlântica na Juréia, Iguape - SP. Tese de Livre-docência, Dissertação de Mestrado, IB USP, São Paulo, 126p.

MAY, R. P., 1975, Patterns of species abundance and diversity, pp. 81-120. In: R. L. Cody \& J. M. Diamond (eds.), Ecology and evolution of communities. Harvard University Press, Cambridge, MA.

ODUM, E. P., 1969, The strategy of ecosystem development. Science, 164: 262-270.

PAGANO, S. N., LEITÃO, H. F. \& CAVASSAN, O., 1995, Variação temporal da composição florística e estrutura fitossociológica de uma floresta mesófila semidecídua Rio Claro - Estado de São Paulo. Revista Brasileira de Biologia, 55: 241-258.

PEARSON, T. H. \& ROSENBERG, R., 1978, Macrobenthic succession in relation to organic enrichment and pollution of the marine environment. Oceanography and Marine Biology, an Annual Review, 16: 229-311. 
PICKETT, S. T. A., 1976, Succession: An evolutionary interpretation. The American Naturalist, 110: 107-119.

PIELOU, E. C., 1976, Mathematical Ecology. Wiley Interscience, New York, 385p.

QINGHONG, L., 1995, A model for species diversity monitoring at community level and its applications. Environmental Monitoring and Assessment, 34: 271-287.

RODRIGUES, R. R., 1995, A sucessão florestal, pp.30-35. In: P. C. Morellato \& H. F. Leitão Filho (eds.), Ecologia e preservação de uma floresta tropical urbana, reserva de Santa Genebra. UNICAMP, Campinas (SP).

RODRIGUES, T. \& SHEPHERD, G. Levantamento fitossociológico da mata da fazenda Santa Genebra, município de Campinas, SP (unpublished report).

ROIZMAN, L. G., 1993, Fitossociologia e dinâmica do banco de sementes de populações arbóreas de florestas secundárias em São Paulo, SP. Dissertação de Mestrado, IB/USP, SP, 184p.
SANCHEZ, M., 1994, Florística e fitossociologia da vegetação arbórea nas margens do Rio da Fazenda (Parque Estadual da Serra do Mar - Núcleo Picinguaba - Ubatuba, SP). Dissertação de Mestrado, IB/UNESP, Rio Claro, 75p.

SOKAL, R. R. \& ROHLF, F. J., 1995, Biometry. $3^{\text {nd }}$ ed. W.H. Freeman and Company, 887p.

TABARELLI, M., 1994, Clareiras naturais e a dinâmica sucessional de um trecho de floresta da Serra da Cantareira, SP. Dissertação de Mestrado, IB/SP, São Paulo, 143p.

WHITMORE, T. C., 1989, Canopy gaps and the two major groups of forest trees. Ecology, 70: 536-538.

ZAJAC, R. N. \& WHITLATCH, R. B., 1982, Responses of estuarine infauna to disturbance. II. Spatial and temporal variation of succession. Marine Ecology - Progress Series, 10: $15-27$. 